\title{
Problems in Making International Financial Reporting Standards Become "National": The Case of Turkey
}

\author{
Kerem Sarığglu
}

\begin{abstract}
Among numerous countries adopting International Financial Reporting Standards, Turkey is a country where the entire set is translated to Turkish and approved it as national accounting standards. Considering its history and the country's established tax based accounting and business culture, using rules that were originated in another language creates problems both in understanding and applying Turkish Accounting Standards. The purpose of this text is to illustrate some of the examples of difficulties in applying Turkish Accounting Standards and to explain past and current financial reporting environment in Turkey.
\end{abstract}

Keywords: International Financial Reporting Standards, International Accounting Standards, Language, Business Culture, Accounting Culture

JEL Classification: M41, M48

\section{Introduction}

International Financial Reporting Standards (IFRS) have been increasingly under the focus of accounting professionals and legislators around the world in the last two decades. In Turkey, IFRS has been used in financial reporting by a limited number of companies for this period. The scope of mandatory application of IFRS was for public companies and financial institutions only. During this time, voluntary applications comprised mostly financial reports of local branches of international corporations. Other two groups that could be named as "IFRS followers" in Turkey were professionals worked for international big auditing firms and academics worked in higher education institutions.

After several attempts, a full set official Turkish translation of IFRS has been published by a semiautonomous professional agency in 2002. Although this set of rules is exact, word by word translation of IFRS, it was titled as "Turkish Accounting Standards" (Türkiye Muhasebe Standartları - TMS). Under this heading, both IFRS and IAS (International Accounting Standards) are translated as Turkish Financial Reporting Standards (TFRS - Türkiye Finansal Raporlama Standartları) and Turkish Accounting Standards (TMS) respectively. Before the new Turkish Commercial Code's becoming in effect in July 2012, entities that were obliged to use TMS were limited to public companies, banks and insurance companies.

Today, even after the new Turkish Commercial Code, it is still legally uncertain whether the TMS is the only set of rules to be used in financial reporting or not. After several changes made in the new law, as of this paper is being composed, the new code implicitly commands that companies are still primarily

${ }^{a}$ Assoc. Prof., PhD., Istanbul University, Faculty of Business Administration, Department of Accounting, Istanbul, Turkiye, keremsa@istanbul.edu.tr 
required to keep accounting records according to tax accounting rules and submit tax purpose financial statements first. With this prioritization of tax accounting, the law still defines "all business entities" and socalled "the merchants" as TMS appliers. However, a newly established governmental agency, "Public Oversight, Accounting and Auditing Standards Board - POOAASB" (Kamu Gözetimi Kurumu - KGK) limited the application of TMS by giving the greater emphasize on auditing.

As of the beginning 2017, after several changes, for non-financial and non-public companies, only the ones meeting certain threshold (based number of employees, amount of turnover, amount of total assets) are required to issue audited financial statements. Although, it is stated that, financial statements of those entities that are subject to independent auditing are to show a true and fair picture of the financial position, financial performance and the changes in financial position, it has not been stated clearly which set of accounting standards would be used in doing that. Those that are to be audited, do not have to prepare financial statements according to TMS. If they wish they can choose not to apply TMS and still be audited. For these there is a guidance issued by POAASB that defines limited number of adjustments in original tax based financial statements for certain items only. In the case of TMS application, the conversion process requires much greater deal of work to be done on the tax based financial statements.

Although, it is not approved as the only set of financial reporting rules in Turkey, TMS greatly attracts the interest of accounting professionals in Turkey for some time. The author of this paper was involved in many educational programs either as an educator or as a participant for the last several years. Based on the interactions with accounting professionals that were striving to come to an understanding of TMS, one can easily say that there was significant amount of hardship felt among many accountants. Of course to name these hardships and to diagnose the root causes of them, more scientific research is necessary. Unfortunately, to conduct such a research project is extraordinarily difficult due to the fact that measurement of variables in such a research model is too indirect.

In this article, probable reasons of the difficulties in understanding and applying TMS (or IFRS in Turkish) in Turkey were laid out with an historical background for the interest of researchers as an undiscovered area of study.

\section{Literature Review}

As significant number of countries made the decision of adopting or converging to IFRS, more researchers in different countries conducted research, each approaching this development from different perspectives.

In 2004, Larson and Street gave one of the first insight for the expected future of IFRS adoption in Europe. The conclusion they reach in their study indicated the first signs of dual accounting systems in IFRS adopting countries. In other words with the increasing number of countries adopting IFRS, emergence of a "two-standard" system of financial reporting in many European countries (Larson \& Street, 2004: 91).

Some accounting researchers looked for the reasons behind the adoption of IFRS in different countries. One example can be given from the empirical study of Clemets, Neill and Stovall. In this particular study, Clement and his co-authors found that IFRS adoption decision is significantly related to the size of country. They conclude that larger countries are less likely to adopt IFRS than small countries, suggesting that larger countries have a well-established set of financial accounting and reporting standards already in place, and therefore would be reluctant to incur the costs of changing to an international set of standards (Clement, Neill \& Stovall, 2010: 115).

When the reasons of widespread adoption of IFRS in many countries throughout the world in recent years analyzed by the researchers, it has been found by some that economic reasons did not play a significant role in the decision of adoption despite it had been expected the otherwise. As an example, Lasmin, in his research published in 2012, found that IFRS adoption in developing countries is significantly related to social pressures of isomorphic changes, rather than to any economic benefits. A set of accounting standards does 
not develop in a vacuum. Political, economic, and social aspects of the jurisdiction in which a set of standards operates reciprocally influence these standards (Lasmin, 2011: 115).

The studies conducted in Turkey for IFRS application, it can be seen that most of them are focusing on either the degree of voluntary application of local businesses or the degree of awareness of IFRS among Turkish Accounting Professionals. One example of these studies is the one by Kılıç, Uyar and Ataman. In their research article based on a survey they tried to find whether any of the determinants of size, leverage, listing status, training, profitability and foreign ownership has a positive impact on preparedness level of reporting entities in Turkeys for the application of IFRS. In their research, level of compliance is measured by conducting a survey (Kılıç, Uyar \& Ataman, 2016).

It is clear to accounting researchers that variety and number of studies in the area of IFRS is immerse. When looked into closely, it can be argued that the variety and size of the research in this area may be affected by the culture which from the researches come.

\section{Standard Setting in Turkey}

\subsection{History}

Today's Turkey that spreads over the land of Anatolia and Eastern Thrace was under the ruling of Ottoman Empire before the establishment of the Republic of Turkey in 1923. Therefore, when evolution of financial reporting in Turkey looked into closely, it is wise to start with the late Ottoman time. It can be seen that there are three time periods that accounting and financial reporting influenced by different countries' accounting cultures. The first period started late 1800's and lasted until 1950's under French influence. The second period lasted until 1990's under German influence. After 1990's, accounting and financial reporting climate in Turkey was funneled towards a model which is mixture of Anglo-Saxon accounting model and the tax tradition. This development followed introduction of Unified Accounting Application System Regulation in 1993. This regulation imposed the usage of a single standardized set of financial reports by all corporate tax payers. The governmental authority behind that regulation is the Ministry of Finance of Turkey. During the first years of application the ministry of finance regulated that this set consisted of balance sheet, income statement, cash flow statement and statement of changes in equity. However due to real substance of the need for creating a unified system was controlling tax filings, cash flow statement and statement of changes in equity were sidelined by the same regulator. Especially during the last part of this period financial reporting in Turkey witnessed a separation between the actual financial information needs of businesses and the official financial reports that were prepared according to tax regulations.

Due to fact that most of the trade handed by the foreign merchants mainly in Istanbul during the Ottoman time, Turkey's accounting history does not start from very far. There was not any organized businesses other than small local shops and free merchants until middle of 1800's in Today's Land of Turkey under the rule of Ottoman, financial reporting was at importance of the state and of the accounts for charity funds (vakif). With the arrival of new businesses from Europe in the 19th century, in 1850 the first Merchant Law legislated by the Ottoman Empire. This regulation was simply a translation of French Merchant Law. Accounting application was also under a strong French influence simply because of that foreign investments are mostly with French origin. During the last decades of the 19th Century, accounting education was also strongly affected by the French accounting literature. First accounting course was in the curriculum of the first merchant school established in 1883. In this and similar schools, with the usage of accounting books translated from French books, accounting application was influenced by French accounting system heavily. This effect remained and influenced the Merchant Law passed in the new Turkish Republic's Parliament in 1926 (Aysan, Sarıoğlu \& Sarıoğlu, 1998:15).

In Turkish Republic, with the establishment of new enterprises ran and owned by the state, the accounting application and financial reporting started improving on a different course. The first example of such enterprises (Kamu Iktisadi Tesebbusleri - KIT: Public Economic Enterprises) was "Sanayii ve Maaddin Bankasi", a bank created funds for the establishments of KITs. In the beginning of 1930's the accounting 
systems of these enterprises were created by a German professor, Sachenberg. Being an application of "Standard Costing System" in the beginning, with the difficulties in implementing phase, it was changed to an "Actual Costing System". Accepted as a revolutionary improvement in accounting in Turkey, the system created by Sachenberg, included a unified chart of accounts especially designed for KIT's, which has still a lot in common with today's standard chart of accounts for mandatory all companies in Turkey. This significant improvement has not been carried forward for almost 40 years. Until late 1970's, free market rules were not in effect and the state was overly active in the local economy in modern Turkey (Aysan et al., 1998: 16).

With the development of private sector and new foreign investments starting from mid 1970's accounting application improved rapidly. In 1981 Law of Capital Market was enacted and The Capital Market Board of Turkey was established as the regulatory body for banking and insurance industries and for securities exchanges.

In 1989 the law for Independent Accountancy and Financial Consultancy was enacted as the first ever legislation governing accounting profession, establishing chambers for the profession.

In 2002 during the aftermath of the big financial crisis in Turkey, Banking Regulation and Supervision Agency of Turkey (Bankacilik Duzenleme ve Denetleme Kurumu - BDDK) issued a communique that required use of a new set of accounting standards that are similar to IFRS for Banks in Turkey. The Capital Market Board of Turkey (Sermaye Piyasası Kurulu - SPK) followed this move by issuing its own accounting standards which was also parallel to IFRS for public companies in 2003.

\subsection{Financial Reporting in Turkey Today}

In today's Turkey, there are two different sets of accounting rules in effect. The first and the most widely used (almost by all corporate tax payers) is the valuation rules of the Tax Procedural Law (VUK) (named as the third book) together with "The Communique on Application of Unified Accounting System". In this paper, the first group of accounting rules are referred as "tax based accounting" or "VUK" in short. The second is Turkish Accounting Standards (TMS), which is exact translation of IFRS.

on the accounting and business culture of country of origin, an international researcher may ask about the national accounting standards of Turkey. Although some may refer to current widely used tax based accounting as national accounting standards, as stated before, these are not comply fully even with basic accounting principles that does not change from one country to another. The reason of some professionals' misplacing tax accounting rules with generally accepted accounting principles may be because of them not having experienced any environment where tax rules does not govern financial reporting.

To clear any confusion, Turkey's convergence is not a real convergence since there has never been any national standard to converge. The ones existed before and now was tax based accounting rules. Considering Turkey's still keeping the old rules, it can be said that there was not any national accounting standards.

As explained in introduction of this paper, there has been several changes in regulations for financial reporting with a greater emphasis on auditing. Currently, other than public companies and financial institutions, companies that are subject to auditing, it is a voluntary application in which companies can choose either fully comply with TMS or make certain financial statement adjustments according to a Communique of POAASB . In any case this preparation is a conversion process that includes elimination of differences between tax accounting rules and accounting rules to different degrees. In the case of TMS application the conversion process requires a great deal of work to be done on the tax based financial statements. On contrary, choosing the application of communique of POAASB for minor changes is easier.

As a result of the discussion above, it can be asked how certain decisions such as loan agreements or share transfers were being taken with the absence of financial statements based on proper accounting rules. There are several answers to this question. If we take bank loan process as an example, even today, significant number of companies present their tax based financial statements when applying for a new loan. In 2016, 44\% (Industry Balance Sheet Reports, Turkish Republic Central Bank of Turkey) of total outstanding bank 
loans in Turkey are given to small and medium size enterprises (SME's). When converted to number of loan files, this share ought to be expected be greater. These companies, presumably, are not in position of allocating their resources to prepare additional set of financial statements according to TMS, when applying for a new loan.

\section{Problems in Making International Standards Become National in Turkey}

Introduction of Turkish translation of International Financial Reporting Standards as National Standards created a great deal of confusion among professionals. According to the author of this article a typical approach seen in international publication related with problems in convergence projects in other countries may not be applied in the particular case of Turkey. The reason may not only because these standards' not being national, it may be because that in Turkish case there was not any accounting rules other than tax rules at all before. With this root cause, making a set of international accounting rules be national rules creates many problems in perception of the rules of financial reporting. Based on observations of the author of this paper these problems can be classified as follows:
a. Language Problem
b. Problems Stem From Different Accounting and Business Cultures
c. Problems from Tax Regulated Books

\subsection{Language Problem}

This part should not be mistaken with the problems in Turkish translation of IFRS. According to the author of this text, although it is true that translating such a long text with a technical content is an extraordinarily difficult task, the language problems causing difficulties in applying TMS are beyond that simple translational mistakes that can be revised and corrected in time.

What meant by "Language Problem" is that it is not only the original language of the standards is English, it is also the way the language is used is different in English than the way the language is used in Turkish. To be more specific, it is not that there are two separate languages, it is that there are two different ways of explaining concepts and telling rules. As in many different languages, there are different words to explain the same. However what really distinguishes languages from each other is not those different words but the different methods of communicating and explaining things.

There are research focusing on the differences in perception between speakers of different language found that probability expressions are perceived differently in different languages. For example the interpretation of uncertainty expressions such as "probable" can be perceived different when translated to another language. Doupnik and Riccio provided further evidence of differences in interpretation of uncertainty expression in translation (Doupnik \& Riccio,2006: 243).

According to Sapir-Whorf hypothesis, the language habits of a community predispose certain choices of interpretation, thereby causing the members of the community to see and hear and otherwise experience accordingly. According to this theory, certain features of a language might very probably have inhibiting influences on out thinking (Oppenheimer, 1961: 64-67). Evans, explored the relevance of the Sapir-Whorf hypothesis for accounting. This hypothesis suggests that linguistic categories affect thought and perception. This, in turn, has implications for translation, also in accounting (Evans, 2004: 211).

For the case of Turkey, one example can be given from IAS 16 Property Plant and Equipment (TMS 16 Maddi Duran Varlıklar). The part (paragraph 43) in the original text explaining "depreciation", starts with indicating that each significant part of a depreciable asset needs to be depreciated separately. It is only after this introduction where it is explained (in paragraph 45) that significant parts with similar economical useful lives can be grouped in calculating depreciation. Based on observations in more than one instance, this, when translated to Turkish in the same order, creates confusion among professionals, although tax accounting rules are similar about this aspect of depreciation. The reason of this confusion may because of the order in which this particular issue is explained. Commonly, legal texts in Turkey, when explaining a concept, starts 
with the most general, and then go into details of explaining particular cases where it is difficult to fit in the most general. In the case of text for depreciation rules in IAS 16, because it was translated word by word with the same order as the original texts, the Turkish version of depreciation in IAS 16 starts with a case which cannot be an example for the most general. An accounting professional with an expectation of significantly different rules in reporting, this and many parts in IFRS similar to this, creates confusion. The author of this paper witnessed more than one professional incorrectly stating that each and every part of a motor vehicle needs to be depreciated separately based on TMS 16 (translation of IAS 16).

Another example for a language problem can be given from IAS 39 Financial Instruments: Recognition and Measurement (TMS 39 Finansal Araçlar: Muhasebeleştirme ve Ölçme). In Turkey, as defined in measurement concepts in tax procedural law, "cost" is the amount of payments and related expenditures for the acquisition of an asset or for an increase in the economic value of an asset. As translated from IAS 39 to Turkish in TMS 39, the phrase "amortised cost" do not fit this definition as explained as the measurement method for certain financial assets and liabilities. To be specific, amortised cost of a receivable may mean different than present value of receivables to an accountant. As a result of an ordinary course of conducting commercial activities of businesses other than financial institutions, a receivable is not something "purchased" or "acquired" therefore, in Turkish, using the term "cost" can be confusing for preparers.

\subsection{Problems Stem From Different Accounting and Business Cultures}

Nobes in his article in 2006 asks the following question to illustrate accounting culture differences: "Asset impairment losses are tax deductible in Germany but not in the UK, Would that influence a company in the UK no to recognize an impairment loss, using its judgement appropriately, as opposed to a German company that might like the tax deduction and therefore may be willing to show the loss in its financial statements?" (Nobes, 2006: 235).

In Turkey, traditionally, accounting is seen as a tool for tax collection. This characteristic together with the tight fiscal policies of the government, caused organizations to spend significant portion of their accounting resources on tax filings only. As a result, a type of professional behavior, which does not have any room for assumptions or estimations about future in financial reporting, embedded in the accounting culture of each reporting entity.

One example can be given from measuring inventories. With the domination of tax rules over accounting applications, In Turkey, tax regulations discourage companies expensing of cost of stocks as impairment. In most cases only for the stocks of no value, with the proper authorization based on a physical inspection of tax officers, it is possible to report inventories at net realizable value. In tax regulations, there is no room for estimations that can be made by the management of the entity, for the possible future net realizable value of inventories. Since detailed balance sheets and income statements are submitted electronically to tax office together with the tax declarations, accounting professionals who may be afraid of any possible tax inspection may not want to increase discrepancies between financial statements and tax declarations, therefore may choose not to expense any amount at all, until it is deductible from taxable income too. When it comes to converting tax based reports to financial statements according to TMS, this way of thinking prevent professionals avoid to make estimations.

Another example of current accounting culture that is problematic in applying TMS can be given from cases of impairments in property plant and equipment. Testing impairment in such assets requires to make estimations about future according to TMS 16 and TMS 36 (IAS 16 and IAS 36). Particularly finding "value in use" (or entity specific value) of those assets that are being tested may become a problematic issue for accountants in Turkey.

As seen in the examples above, it can be said that established accounting culture in Turkey does not favor professional judgement, especially in cases of impairments. This may create a lack of understanding and inappropriate application of TMS. 
Accounting rules are developed over time based on the needs of businesses. Rule setting is an ongoing never ending process because of the fact that new ways of doing business create new types of assets and liabilities. As the variety of business practices expands, the need for ungoverned areas refreshes. One important factor in deciding an accounting rule is the way different business cultures do businesses. What makes international standard setting too difficult is that fact. Finding a standard rule for a particular business transaction in one business culture may not have any reciprocate in another. Therefore a complete abandonment of national standards is not seen a good solution in converging with IFRS in certain countries such as the USA, Germany and France. In case of Turkey, making international standards become national caused problem from this aspect too.

Nobes in a more recent article (Nobes, 2013: 84), explains that in certain jurisdictions where IFRS are required or allowed, this is often restricted in various ways. He continues that this fact suggests that these restrictions cause and unadorned statement about "adoption" to be misleading.

One example of is in TMS 19 (IAS 19). In Turkish business practice, there is no term for "defined benefit plan". In Turkey, practice of determining long term benefits in an employment contract is not common between employer and employee. In other words, in most of the cases there is no long term obligation per se "defined" by the employment contract between employees and employers. Instead of contractual long term obligation based on private clauses particularly specific to each employment contract, there is a standard obligation by law that is implicit to all employment contracts. The method of calculation and the maximum allowable amount is defined by law not by entities. This amount is named as "severance compensation", or in Turkish "Kıdem Tazminat". The amount of this obligation is based on the number of years of service and the latest monthly gross salary. This is the only long term benefit that employers may or may not pay in long term. It is a legal obligation of the employer on conditions with certain legal limits. This obligation is imposed by labor law on all employers. Yet, the term for "defined benefit plan" used in Turkish translation was a made up term with no existence previously in any kind of literature, financial report, accounting application or any regulation in Turkish. Even in Turkish Labor Law there is no such term as "defined benefit plan". In addition, no business entity is obliged to keep assets that will be used to compensate accumulated severance pay. Therefore all the rules explained in IAS 19 for "defined benefit plan assets" have no reciprocate.

Some international standards when put into effect without making any change in Turkish financial reporting, may not achieve the intended purpose. An example for this can be given from TMS 24 (IAS 24). As stated in paragraph 6 of the original standard to explain the purpose of the standard, "related parties may enter into transactions that unrelated parties would not." This is one of the reasons why related party transactions and outstanding balances with other entities in a groupware disclosed in an entity's financial statements. When possible related parties are listed in the standard, close members of the family are also considered as related party. However in Turkey to answer who close member of family is, the following definition made in paragraph 9 of the original standard may not be sufficient to achieve the purpose of the standards:

"Close members of the family of a person are those family members who may be expected to influence, or be influenced by, that person in their dealings with the entity and include:

(a) that person's children and spouse or domestic partner;

(b) children of that person's spouse or domestic partner; and

(c) dependants of that person or that person's spouse or domestic partner."

One, who experienced Turkish business practice well enough can easily say that, definition of a close family member that an entity may enter into transactions that unrelated parties would not, can go well beyond this definition of IAS 24. Because it has translated to Turkish in these exact words, it may not be said that the purpose of the standard is met in Turkish financial reports under TMS. 


\subsection{Problems Arising From Tax Based Accounting Books}

One can easily say that applying one countries own accounting standards naturally result in financial transactions' being recorded in official accounting books according to those standards. However, this is not true in Turkish Case. Under current legal environment in Turkey, practitioners, cannot apply rules of Turkish Accounting Standards in accounting books. Even conversion process for the differences between tax accounting rules and TMS cannot be made in official books of reporting entities. This is because that Turkish Tax Procedural law still defines accounting books and mandates even accounting records made in certain way to be eligible for different tax incentives and deductions.

With this limitation, all conversion entries are made outside of accounting books. Depending on the resources available for accounting and financial reporting in different entities, the media in which conversion process is done and kept can be separate financial reporting software or a secondary set of unofficial books or in most of the cases electronic spreadsheets.

Problems of not having accounting adjustments in official books are tremendous. Because official books do not carry IFRS adjustments from one year to another, items that are outside of scope of tax accounting must be included over and over again at every period in converting tax based financials to TMS. Similarly, items that are outside of scope of TMS financial statements must be excluded from tax accounting data in transforming financials to TMS every year.

\section{Conclusion}

To conclude, Turkish Case of IFRS adoption can be categorized as the one without any national accounting standard before the arrival of IFRS. As in many different countries, having a complete translation of IFRS can be guiding for converging national standards over time. The purpose of translating IFRS to Turkish however manifested itself in a different way. Without the existence of any national accounting rules constituting a rhetoric that is suitable for Turkish business culture, naming IFRS in Turkish as national standards may prevent business entities to practice better financial reporting.

One solution to this problem is to change the title of "TMS" to "IFRS in Turkish" and replace it with zero based national financial reporting standards. This however does not mean that this new TMS will result in different measurements and presentations, when compared to IFRS statements. In fact, a much more understandable text with rules resulting in financial statements with the same measurement and presentation principles is a possible achievement.

Finally, as described in literature review, most of the research about TMS are focusing on either the level of preparedness or the degree of adoption. To reflect the need for a new set of standards and attract the attention of professional and regulatory bodies, more research and case studies must be conducted dealing with the problems specific to Turkish standard setting case.

\section{References}

Aysan, M., Sarıŏlu, B., \& Sarıoğlu K., (1998). Muhasebe tarihi. Ankara: TÜRMOB Yayınları

Clements, C.E., Neill J.D., \& Stovall, O.S. (2010). Cultural diversity, country size, and the IFRS adoption decision. Journal of Applied Business Research, 26(2), 115-126.

Doupnik, T.S., \& Riccio, E.L. (2006). The influence of conservatism and secrecy on the interpretation of verbal probability expressions in the Anglo and Latin cultural areas. The International Journal of Accounting, 41(3), 237-261.

Evans, L. (2004). Language, translation and the problem of international accounting communication. Accounting, Auditing \& Accountability Journal, 17(2), 210-248.

Kılıç, M., Uyar, A., \& Ataman, B. (2016). Preparedness of the entities for the IFRS for SMEs: An emerging country case. Journal of Accounting in Emerging Economies, 6(2), 156-178.

Larson, R.K., \& Street, D.L. (2004). Convergence with IFRS in an expanding Europe: Progress and obstacles identified by large accounting firms' survey. Journal of International Accounting, Auditing and Taxation, 13, 89-119 
Lasmin, R. (2011). An institutional perspective on International Financial Reporting Standards adoption in developing countries. Academy of Accounting \& Financial Studies Journal, 16, Special Issue, 115 - 125.

Nobes, C. (2013). The continued survival of international differences under IFRS. Accounting and Business Research, 43(2), 83-111.

Nobes, C. (2006). The survival of international differences under IFRS: Towards a research agenda. Accounting and Business Research, 36(3), 233-245.

Oppenheimer, M.Jr. (1961). The bane of our linguistic insensibility. The Modern Language Journal, 45(2), 64-67.

Turkish Republic Central Bank, Industry Balance Sheet Reports http://www.tcmb.gov.tr/wps/wcm/connect/tcmb+tr/tcmb+tr/main+menu/istatistikler/reel+sektor+istatistikler i/sektor+bilancolari

International Accounting Standard 16 - Property Plant and Equipment.

International Accounting Standard 19 - Employee Benefits.

International Accounting Standard 24 - Related Party Disclosures.

International Accounting Standard 36 - Impairment of Assets.

International Accounting Standard 39 - Financial Instruments: Recognition and Measurement.

Türkiye Muhasebe Standardı 16 - Maddi Duran Varlıklar.

Türkiye Muhasebe Standardı 19 - Çalışanlara Sağlanan Faydalar.

Türkiye Muhasebe Standardı 24 - İlişkili Taraf Açıklamaları.

Türkiye Muhasebe Standardı 36 - Varlıklarda Değer Düşüklüğü.

Türkiye Muhasebe Standardı 39 - Finansal Araçlar: Muhasebeleştirme ve Ölçme 
This Page Intentionally Left Blank 